\title{
Neighbourhood responses to drought in the Western Cape
}

\author{
Stephen Rule $($ D $\cdot$ Saahier Parker - Yamkela Majikijela $\cdot$ Wilfred Lunga
}

Published online: 9 April 2020

(C) Springer Nature B.V. 2020

\begin{abstract}
An extreme drought event occurred in the Western Cape when the mean level of water supply dams declined to $28 \%$ of capacity in August 2017 (Odendaal 2019). Our survey of 240 households and 71 businesses identified neighbourhood variations in response to the drought and to local government restrictions in water usage, and in the methods of adaptation that were implemented to mitigate the impact of the disaster. Whereas water consumption declined dramatically in comparison with drought responses in other contexts (Shaw et al. in Am Water Works Assoc 84(10):34-41, 1992, https://doi.org/10. 1002/j.1551-8833.1992.tb05862.x; Miller and Buys in Soc Nat Resour 21(3):244-257, 2008; Buurman et al. in Int J Water Resour Dev 33(1):31-50, 2017, https:// doi.org/10.1080/07900627.2016.1138398; Okaka and Odhiambo in S Afr Geogr J 100(3):378-393, 2018), significant variations in attitude and behaviour emerged between respondents of Western Cape neighbourhoods with different socio-economic profiles. Middle class and older households and waterintensive businesses or organisations were more likely to report substantial decreases in water usage and to be critical of official interventions than were poorer or younger households and small businesses.
\end{abstract}

S. Rule $(\bowtie) \cdot$ S. Parker · Y. Majikijela · W. Lunga Human Sciences Research Council, 116 Buitengracht Street, Cape Town 8001, South Africa

e-mail: srule@hsrc.ac.za
Keywords Drought - Adaptation · Neighbourhood · Water restrictions $\cdot$ Conservation

\section{Introduction}

After the winter rain of 2017, dams that supply water to Cape Town were only $38.5 \%$ full. Whereas the drought extended across the Western Cape and into adjacent provinces (News24 2019), Cape Town's vibrant tourism industry catapulted news of the city's predicament into the international media. The city management published several alerts and warnings, which had little impact on consumer behaviour. An early intervention entailed the establishment of an online 'water dashboard' (City of Cape Town 2019a) to provide ongoing regular updates about the levels of the city's dams. In January 2018, the Mayor of Cape Town, Patricia de Lille, announced that in the absence of rainfall or a change of consumer patterns, the prevailing rate of water consumption would lead to the depletion of the municipal supply by the 16th April 2018. This prospect was designated as 'Day Zero'. Residents of the city were restricted to an allocation of only 50 litres of water per person per day for all purposes. The Mayor requested the national government to declare a disaster in order to ease the mobilisation of resources to mitigate the impact of the drought. Only then did households, businesses and 
organisations begin to grasp the urgency and severity of the drought. Municipal water consumption declined dramatically.

The vulnerability approach is an appropriate lens through which to study adaptation to the drought, factoring in people-centredness and the social, political, and cultural vulnerabilities of communities. Local skills, knowledge and social institutions serve as critical mechanisms for dealing with a disaster (Baumwoll 2008; Daskon and Binns 2010), which are ignored by state or developmental agencies at their peril (Nunn et al. 2007). The likelihood of successfully reducing disaster risk increases if a community is allowed and encouraged to make autonomous decisions regarding adaptive interventions (Hewitt 2007; Berkes 2008; Huntington et al. 2011) that capacitate itself "to better cope with, manage or adjust to some changing condition, stress, hazard, risk or opportunity" (Smit and Wandel 2006, 282). Conversely, maladaptation to climate change risks can result in unintended negative consequences (Magnan et al. 2016). Appropriately, national legislation in the form of the Disaster Management Act, 2002 (Act No.57 of 2002) provides for consultation with communities and stakeholders as a means of reducing disaster risk, and the Disaster Management Amendment Act, 2015 (No. 16) (Republic of South Africa, 2015; van Niekerk 2014) identifies several forms of vulnerability, namely physical, economic, environmental and social, that increase the susceptibility of a community to the impact of a drought or other hazard. The skills and capacity of government and civil society are perceived to be critical to the mitigation of drought risk (Botha and van Niekerk 2013, 9; Mudombi et al. 2017, 1). Moreover, the age of the farmers and the imbalance of decision-making powers between men and women have been shown to increase social vulnerability to drought (Muyambo et al. 2017, 6), while religious beliefs (Schuman et al. 2018, 10) and indigenous knowledge systems in respect of the African and Asian environments (Singh and Singh 2006; Lunga and Musarurwa 2016; Marango et al. 2016; Musarandega et al. 2018) impact on drought or flood disaster reduction by providing for vulnerable families against food and water shortages.

Middle class and older households are more inclined to adapt their water consumption patterns prior to and during drought events than are poorer or younger households (Brooks 1982). In San Francisco, drought response programmes in 1977 were deemed to be fair and effective, with some concerns raised about the clarity and communication of the water conservation plan (Bruvold 1979). A decade later, droughts in Los Angeles and San Diego achieved reduced consumption of up to $25 \%$ (Shaw et al. 1992). Funds are now accessible specifically to poor communities in California for technical assistance and water infrastructure development (Reibel et al. 2020). In Australia, predominantly middle class suburbanites have implemented robust and affordable solutions in response to regular and pervasive droughts (Mortazavi et al. 2013). A high degree of social capital in a community is arguably an indicator of capacity to collaborate in dealing with environmental disasters (Putnam 2000; Selman 2001). One form of social capital, namely Neighbourhood Connections (Onyx and Bullen 2000), was shown to enhance urban water conservation in suburbs where almost half of urban water is used for gardens. A survey of 276 middle class households (Miller and Buys 2008) demonstrated that neighbourhood connections were a predictor of the environmentally-friendly practice of car washing on the garden lawn rather than on the driveway. This resulted in the grey water running directly into the garden, rather than down the driveway and into the municipal storm water drain system. Information about any environmentally-unfriendly behaviour of neighbours could easily spread and thus served as a constraint (Miller and Buys 2008).

Differences in culture, social systems, ecosystem dynamics, topography, beliefs about climate change, socio-economic conditions, and distinct knowledge systems should be factored into the management of resources and sustainable livelihoods (Kamara 2005; Lindner 2008; Mwaura 2008; Birkmann et al. 2010; Campisano and Modica 2009; Nunes 2016; Otto et al. 2017; de Matos Carlos et al. 2019). Failure to heed warnings of disaster and to implement ameliorative strategies constitute a high risk (Muyambo et al. 2017; Mathivha et al. 2017).

\section{Drought in the Western Cape}

Four million of the Western Cape's 6.3 million people live in Cape Town (City of Cape Town 2019b). The city's main water sources are six storage dams, namely Theewaterskloof, Voëlvlei, Bergrivier, Wemmershoek, 
Steenbras Lower and Steenbras Upper, with a combined storage capacity of 898,221 megalitres. They rely on the supply of upstream precipitation in the catchment areas of the Cedarberg, Boland and Langeberg fold mountain belt. After the poor rainfall during the winter of 2016, a local disaster proclamation was issued by the Mayor on the 1st April 2017. This was extended to the entire Western Cape Province in May 2017, and adjacent Northern and Eastern Cape in March 2018. The declarations resulted in a financial allocation of R500million for implementing mitigation measures. The need for greater diversification of water sources became urgent and the construction of three desalination plants and 300 boreholes commenced. Water restrictions of 50 litres per person per day were imposed and the communication and messaging by the authorities resulted in widespread solastalgia (Kaiser and Macleod 2018, 10) or "a feeling of distress associated with environmental change close to home". The effect of the messages was a decline in water consumption: 1200 million litres per day in 2015; 900 million litres in 2017; 520 million litres in March 2018 (Jones 2018). The 'Day Zero' campaign identified the point at which dam capacity would have dropped to $13.5 \%$, after which there would be only six weeks left before no more usable water could be extracted. Although the campaign was subjected to intense criticism, a city official (interview, 18.11.2018) opined that "it was innovative, in your face, and it convinced people that we are serious". He said, "I can't conceive of ever using pure water to flush toilets again..... I've learnt that water is very sacred. ...Cape Town needs to be complimented, the way we have rallied". As Day Zero approached, the city planned and piloted for more than 200 points of distribution where water could be collected from communal standpipes in the event of a shut-off of main supplies to the city grid. Regular meetings were held with the city's Disaster Management Unit staff and 400 volunteers across the city, and with community neighbourhood watch groups, religious organisations, business groups and water experts. Other factors contemplated in the Disaster Risk Reduction planning were how to deal with potential build-up of methane in sewerage works that were not receiving sufficient water; safety and security in the event of a riot; potential epidemic outbreak; and bottled water supply to vulnerable residents.

\section{Survey of residents and businesses}

Our sample survey of households and business or institutional respondents targeted seven broad neighbourhoods in the Western Cape, five in Cape Town, and two in small towns to the north of the city (Fig. 1). Within each, a cluster sample was selected, comprising a minimum of 20 households and five businesses/ institutions. ${ }^{1}$ The localities were chosen to represent the province's diverse communities, socio-economic circumstances, ecologies, political preferences and environments (Table 1). Respondents were either interviewed or requested to complete the questionnaire themselves. Interviews were conducted in one of the three provincial official languages (Afrikaans, isiXhosa or English). The survey yielded 311 responses (Table 2) across the five Cape Town areas (Central Low-Income (CLI); South-East (SE); North (N); Central Middle-Income (CMI); and South (S)) and two small towns, Piketberg and Clanwilliam, respectively $130 \mathrm{~km}$ and $230 \mathrm{~km}$ north of Cape Town.

\section{Impact of the drought}

We asked what impact the drought had made on our respondents, and just over one-third $(32 \%)$ indicated that it had had a small impact on either their households or organisations. A further $30 \%$ said the impact was considerable, while $30 \%$ indicated that the impact had been major. A lower proportion of households (28\%) than businesses/organisations $(38 \%)$ indicated that the drought had had a major impact on their operations. Although geographical differences in response were not statistically significant, the proportions perceiving the impact to have been either major or considerable were highest in CoCT-CMI (75\%) and lowest in Piketberg (51\%). Differences in perception between households about the most serious effects of the drought in the seven areas were statistically significant $\left(\mathrm{X}^{2}=88.741\right.$; $\mathrm{df}=$ 36 ; sig. $=0.000$ ), and mention of the impact on hygiene and health duties ranged from 53\% amongst households in CoCT-North to only $19 \%$ in CoCT-CLI,

\footnotetext{
1 Valuable comparative qualitative data were simultaneously collected by means of key informants across the city, by the University of Cape Town's African Centre for Cities (Ziervogel 2019).
} 


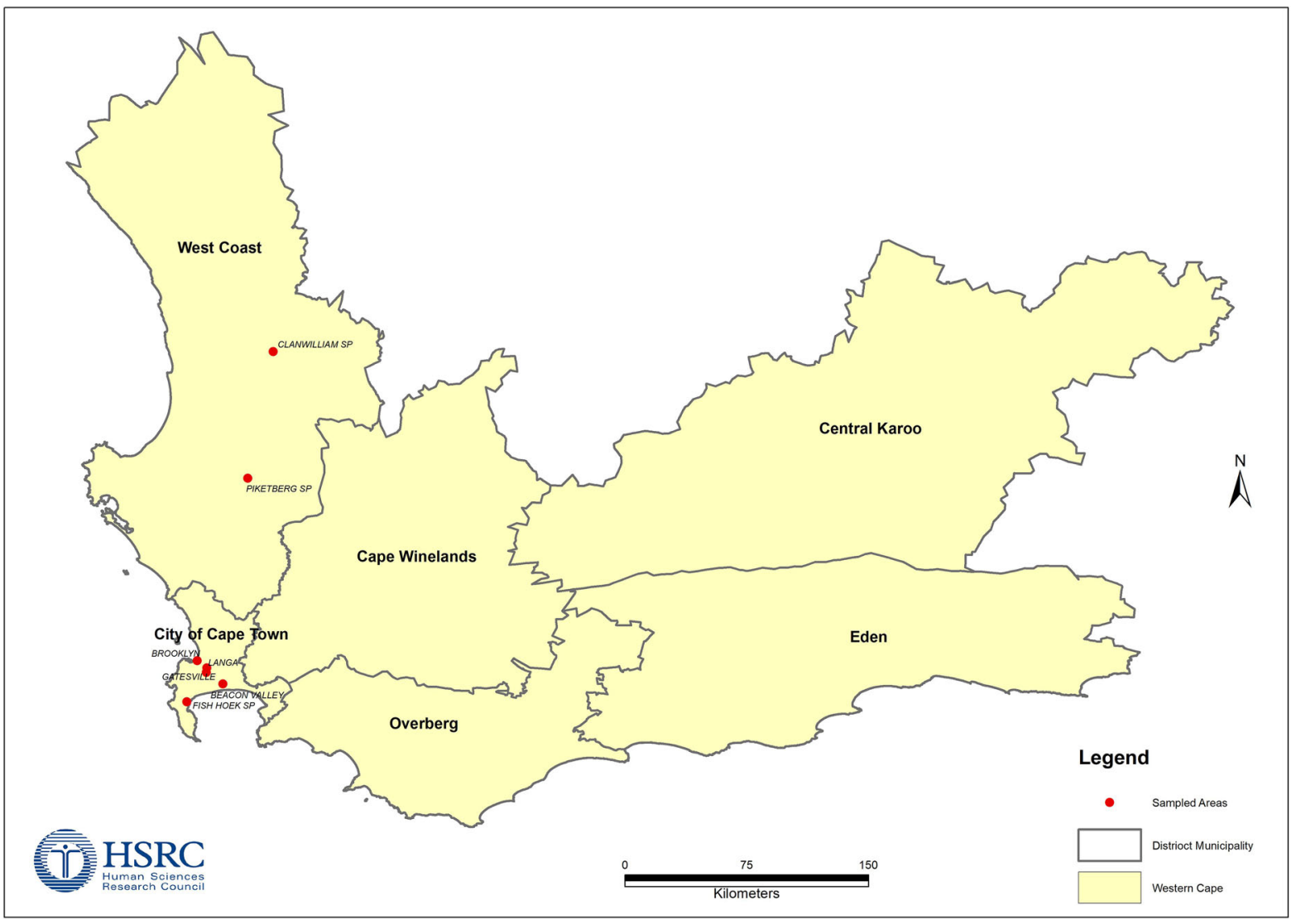

Fig. 1 Western Cape survey sampling points

where health per se was of equal concern and highest of all seven areas (Fig. 2). Table 1 signals several indicators of poverty in CoCT-CLI, namely highest level of informal housing (23\%) and lowest level of employment $(42 \%)$. This poorer neighbourhood is located in Langa, which was established in 1927 exclusively for Black African settlement in terms of the Urban Areas Act of 1923 (SA History 2019). Strongly associated covariation is evident in the highest proportions Black African (99\%) and isiXhosa-speakers $(89 \%)$ and second lowest proportion born within the province (55\%) owing to the large numbers of first generation migrants from the Eastern Cape.

Many of the impacts related to normal daily activities and duties within the home or business enterprise. Hygiene and household duties included daily ablution routines. Common behaviour changes were taking shorter showers, saving bath water for reuse, catchment of grey water, and less frequent laundry and cleaning activities. Within the business environment, the trends were similar, except in respect of water-intensive business operations, where water conservation was less feasible. In businesses involving food processing or retailing, water usage continued as normal. In contrast, the most mentioned serious effect in the two small towns and in CoCT-South, was on gardening activities. Fieldworkers observed much greater evidence of vegetable gardening on domestic properties in Clanwilliam and Piketberg than in Cape Town, which would account for gardening activities being seen as most seriously impacted by the drought in these small towns. In CoCT-South, located within the middle-income suburb of Fish Hoek, the impact was on grass lawns and flower beds. 
Table 1 Mean demographic and other characteristics of survey sample areas

\begin{tabular}{|c|c|c|c|c|c|c|c|c|}
\hline \multicolumn{2}{|c|}{ Household characteristics (\%) } & \multicolumn{7}{|c|}{ Sampling area } \\
\hline & & СoCT-CMI & CoCT-CLI & CoCT-S & CoCT-SE & CoCT-N & Piketberg & Clanwilliam \\
\hline \multirow[t]{2}{*}{ Election 2016} & DA & 76 & 7 & 92 & 89 & 91 & 72 & 64 \\
\hline & $\mathrm{ANC}$ & 9 & 73 & 2 & 2 & 4 & 24 & 30 \\
\hline \multicolumn{2}{|l|}{ Median age } & 29 & 26 & 39 & 27 & 33 & 29 & 29 \\
\hline \multirow[t]{4}{*}{ Race group } & Coloured & 77 & 0 & 17 & 95 & 24 & 72 & 77 \\
\hline & Black African & 7 & 99 & 14 & 3 & 25 & 12 & 14 \\
\hline & White & 0 & 0 & 64 & 0 & 45 & 16 & 9 \\
\hline & Indian & 14 & 0 & 2 & 1 & 4 & 0 & 0 \\
\hline \multirow[t]{3}{*}{ Home language } & Afrikaans & 36 & 1 & 12 & 48 & 19 & 83 & 84 \\
\hline & English & 57 & 3 & 75 & 49 & 59 & 2 & 2 \\
\hline & isiXhosa & 3 & 89 & 1 & 0 & 4 & 1 & 5 \\
\hline \multicolumn{2}{|c|}{ Born in Western Cape } & 91 & 55 & 49 & 96 & 59 & 81 & 83 \\
\hline \multirow[t]{2}{*}{ Housing } & Informal & 7 & 23 & 0 & 3 & 1 & 5 & 10 \\
\hline & Owned & 59 & 29 & 60 & 81 & 42 & 51 & 50 \\
\hline \multicolumn{2}{|l|}{ Employed } & 44 & 42 & 66 & 47 & 62 & 51 & 54 \\
\hline \multicolumn{2}{|c|}{ Internet access on cell phone } & 40 & 37 & 14 & 57 & 25 & 44 & 31 \\
\hline \multicolumn{2}{|c|}{ Grade 12 or higher education } & 41 & 44 & 75 & 32 & 62 & 29 & 23 \\
\hline
\end{tabular}

Table 2 Geographical distribution of survey sample

\begin{tabular}{lccc}
\hline & $\mathrm{n}$ & Business/organisation (\%) & Household (\%) \\
\hline City of Cape Town (CoCT) & & & 81.6 \\
SOUTH-EAST (Mitchell's Plain/Beacon Valley) & 38 & 18.4 & 85.7 \\
CENTRAL MIDDLE-INCOME (Gatesville/Athlone/Bellville) & 28 & 14.3 & 60.6 \\
NORTH (Brooklyn) & 33 & 39.4 & 73.9 \\
SOUTH (Fish Hoek) & 23 & 26.1 & 88.4 \\
CENTRAL LOW-INCOME (Langa) & 69 & 11.6 & \\
Small towns & & & 68.4 \\
CLANWILLIAM & 57 & 31.6 & 76.2 \\
PIKETBERG & 63 & 23.8 & 77.2 \\
\end{tabular}

\section{Awareness of the water restrictions}

Most respondents were aware of the municipallyimposed water restriction, with a peak of unawareness (19\%) in CoCT-CLI. Perspectives on municipal communication about the drought were accordingly most negative (Table 3) in CoCT-CLI. In five areas, half $(50 \%)$ or less thought the authorities had communicated well. In the other two, more than two-thirds held this view. Differences between localities were statistically significant, indicative of the need for greater disaggregation and targeting of future communication strategies.

Overall, a larger proportion of businesses or organisations $(60 \%)$ than households $(51 \%)$ said the authorities had communicated well about the water restrictions. Among households, 29\% indicated that the communication was 'partly' well executed and $20 \%$ said that the authorities did not communicate well. Just over one-fifth $(21 \%)$ of business or 


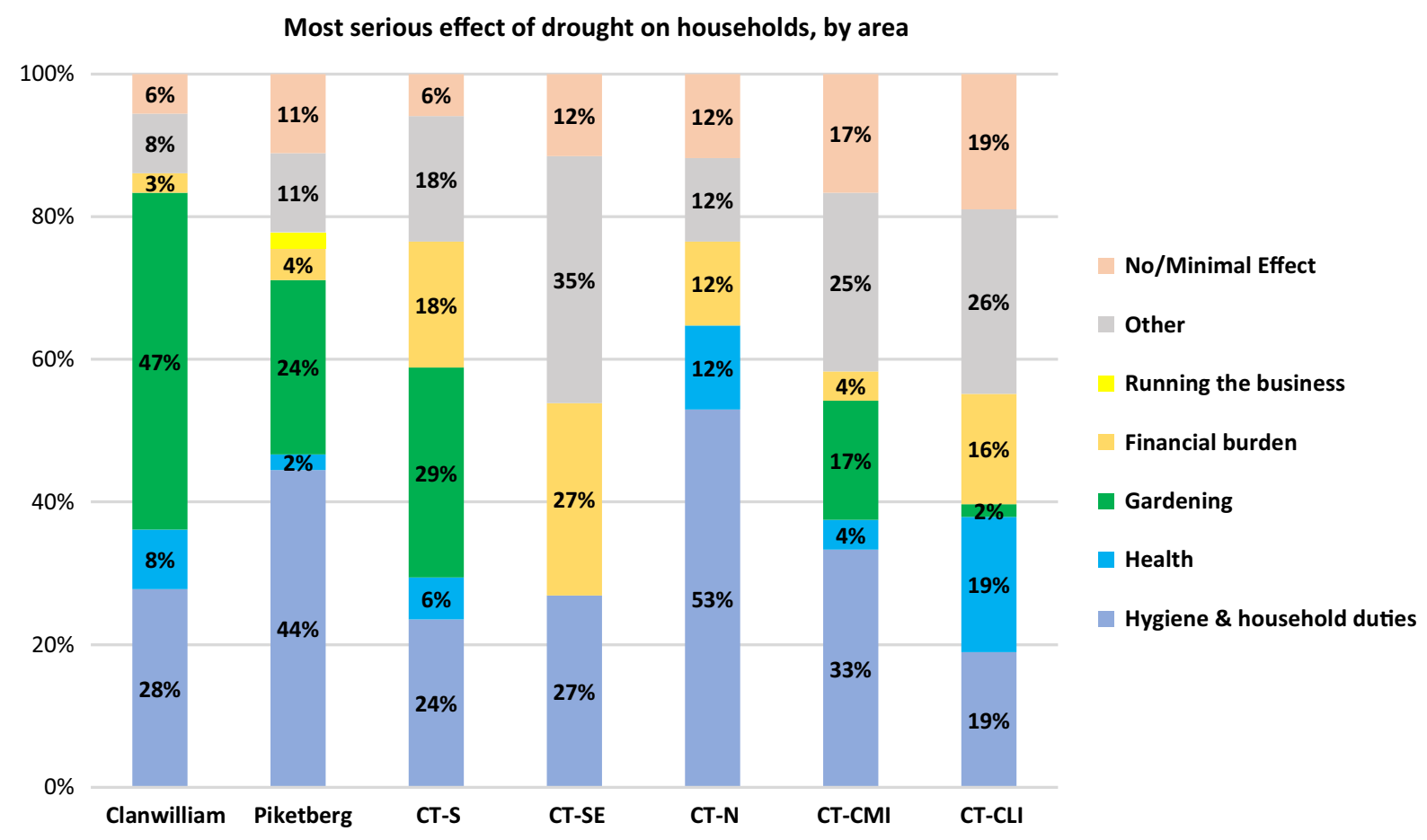

Fig. 2 What was the most serious effect of the drought on your household?

Table 3 Do you think the authorities communicated well about the restrictions?

\begin{tabular}{lcclllrr}
\hline & $\begin{array}{l}\text { Clanwilliam } \\
(\%)\end{array}$ & $\begin{array}{l}\text { Piketberg } \\
(\%)\end{array}$ & $\begin{array}{l}\text { CoCT- } \\
\text { SOUTH-EAST } \\
(\%)\end{array}$ & $\begin{array}{l}\text { CoCT-CENTRAL } \\
\text { MIDDLE-INCOME }(\%)\end{array}$ & $\begin{array}{l}\text { CoCT- } \\
\text { NORTH } \\
(\%)\end{array}$ & $\begin{array}{l}\text { CoCT- } \\
\text { SOUTH } \\
(\%)\end{array}$ & $\begin{array}{l}\text { CoCT-CENTRAL } \\
\text { LOW-INCOME }(\%)\end{array}$ \\
\hline Yes & 48.2 & 67.2 & 47.4 & 75.0 & 50.0 & 45.5 & 42.6 \\
Partly & 35.7 & 14.8 & 26.3 & 21.4 & 34.4 & 45.5 & 25.0 \\
No & 16.1 & 18.0 & 26.3 & 3.6 & 15.6 & 9.1 & 32.4 \\
Total & 100.0 & 100.0 & 100.0 & 100.0 & 100.0 & 100.0 & 100.0 \\
\hline
\end{tabular}

Significance: $\mathrm{X}^{2}=12.811 ; \mathrm{df}=12 ;$ sig. $=0.006$

organisation respondents said that official communication had been partly well done, and $19 \%$ that communication had not been effective. Respondents' views varied about the most appropriate means of communication. Three traditional methods were nominated by more than half of the respondents, namely television $(60 \%)$, radio $(57 \%)$ and posters $(53 \%)$. Less popular were public meetings (42\%), SMS (39\%), WhatsApp (34\%), Email (26\%), the Internet (21\%) and Twitter (15\%). Businesses and organisations were more likely than households to select email (35\% vs. $23 \%$ ), SMS (41\% vs. $38 \%$ ) and WhatsApp (41\% vs. $32 \%)$. The same pattern distinguished younger and older respondents, with those aged 18 to 29 years being more than twice as likely as those aged 50 or older to opt for Twitter, WhatsApp and the Internet. Television was more popular in poorer and small town environments, radio in CoCT-N and CMI. Posters were most popular in the small towns.

\section{Perceptions of changes in water usage during the drought}

The issue of water consumption attracted considerable media, government and public attention. The Day 
Table 4 Do you think that your consumption of water decreased, stayed the same or increased during the last two years?

\begin{tabular}{lcllllll}
\hline & $\begin{array}{l}\text { Clanwilliam } \\
(\%)\end{array}$ & $\begin{array}{l}\text { Piketberg } \\
(\%)\end{array}$ & $\begin{array}{l}\text { CoCT- } \\
\text { SOUTH- } \\
\text { EAST }(\%)\end{array}$ & $\begin{array}{l}\text { CoCT-CENTRAL } \\
\text { MIDDLE-INCOME } \\
(\%)\end{array}$ & $\begin{array}{l}\text { CoCT- } \\
\text { NORTH } \\
(\%)\end{array}$ & $\begin{array}{l}\text { CoCT- } \\
\text { SOUTH } \\
(\%)\end{array}$ & $\begin{array}{l}\text { CoCT-CENTRAL } \\
\text { LOW-INCOME (\%) }\end{array}$ \\
\hline $\begin{array}{l}\text { Increased } \\
\text { Stayed } \\
\text { the }\end{array}$ & 7.0 & 12.9 & 17.9 & 14.3 & 6.7 & 4.3 & 16.2 \\
$\quad$ same & 35.1 & 33.9 & 28.3 & 21.4 & 23.3 & 4.3 & 36.7 \\
$\begin{array}{l}\text { Decreased } \\
\text { Total }\end{array}$ & 57.9 & 53.2 & 53.8 & 64.3 & 70.0 & 91.4 & 47.1 \\
\hline
\end{tabular}

Significance: $\mathrm{X}^{2}=20.486$; $\mathrm{df}=12 ;$ sig. $=0.058$

Zero campaign was particularly focused on encouraging, urging and warning residents to reduce water consumption. The majority (58\%) said that they had reduced their water usage, $30 \%$ said it had remained at the same levels, while $12 \%$ thought that it had actually increased. The latter trend was highest amongst those in the 18-29 year group. Between areas, perceptions of change in water usage differed significantly (Table 4). The largest proportion that reported an increase was in CoCT-CLI (16\%), coinciding with highest reported lack of awareness about the water restrictions. The highest rate of reported decrease was in CoCT-S (91\%).Female respondents were more likely to report that their water usage pattern had either decreased or been similar (91\%), than was the case with males $(84 \%)$.

In respect of actual water consumption, $10 \%$ of respondents were able to provide some data for the period 2016-2018. There was a general pattern of dramatically decreased usage for households (average consumption decreased from 16.8 to 8.9 kilolitres per month) and for businesses and organisations (from 434 to 123 kilolitres per month). Two key drivers of this pattern emerged in our discussions with respondents. These were the increased cost of water owing to higher tariffs; and heightened awareness of the need to save and recycle water (Fig. 3).

The ability to find alternative water sources is in many ways related to financial capacity. Wealthier communities were more likely to afford the cost of installing water catchment tanks, boreholes, purification systems and related infrastructure. A key suggestion, particularly in township and poorer areas was the request for installation of water tanks by the municipality, rather than through individual investment.

\section{Opinions about civic management of the drought situation}

Public opinion about the management of the drought situation (Table 5) was multi-layered and politically tainted within the context of imminent national elections that were to be held in May 2019. Almost half $(43 \%)$ agreed or strongly agreed that the authorities had dealt very effectively with the drought. Just over a third (34\%) indicated disagreement, and $23 \%$ were neutral. Disagreement peaked at $61 \%$ in CoCTCMI, coinciding with a dramatic decline in electoral support for the Democratic Alliance (DA), the ruling party in the City. ${ }^{2}$

Asked in what ways a drought could be better managed in the future, respondents focused on six main themes. Saving water $(22 \%)$ was the most frequent, followed by communication and awareness (19\%) and improving infrastructure and resources $(18 \%)$. Smaller proportions suggested that government should maintain water restrictions $(9 \%)$, provide water tanks (7\%) or install boreholes (6\%). Although differences between areas were not statistically significant, the broad trend was for middle-income areas to ask for better infrastructure while the poorer areas were more likely to mention the imperative to save water.

\footnotetext{
$\overline{2}$ Whereas DA support had been at the $69 \%$ level in one of the Ward 46 voting districts $(97,090,847)$ in the 2014 national election, it decreased to $39 \%$ in the subsequent national election in May 2019. The beneficiary parties were the ANC, GOOD and Al Jama-ah (IEC 2019).
} 

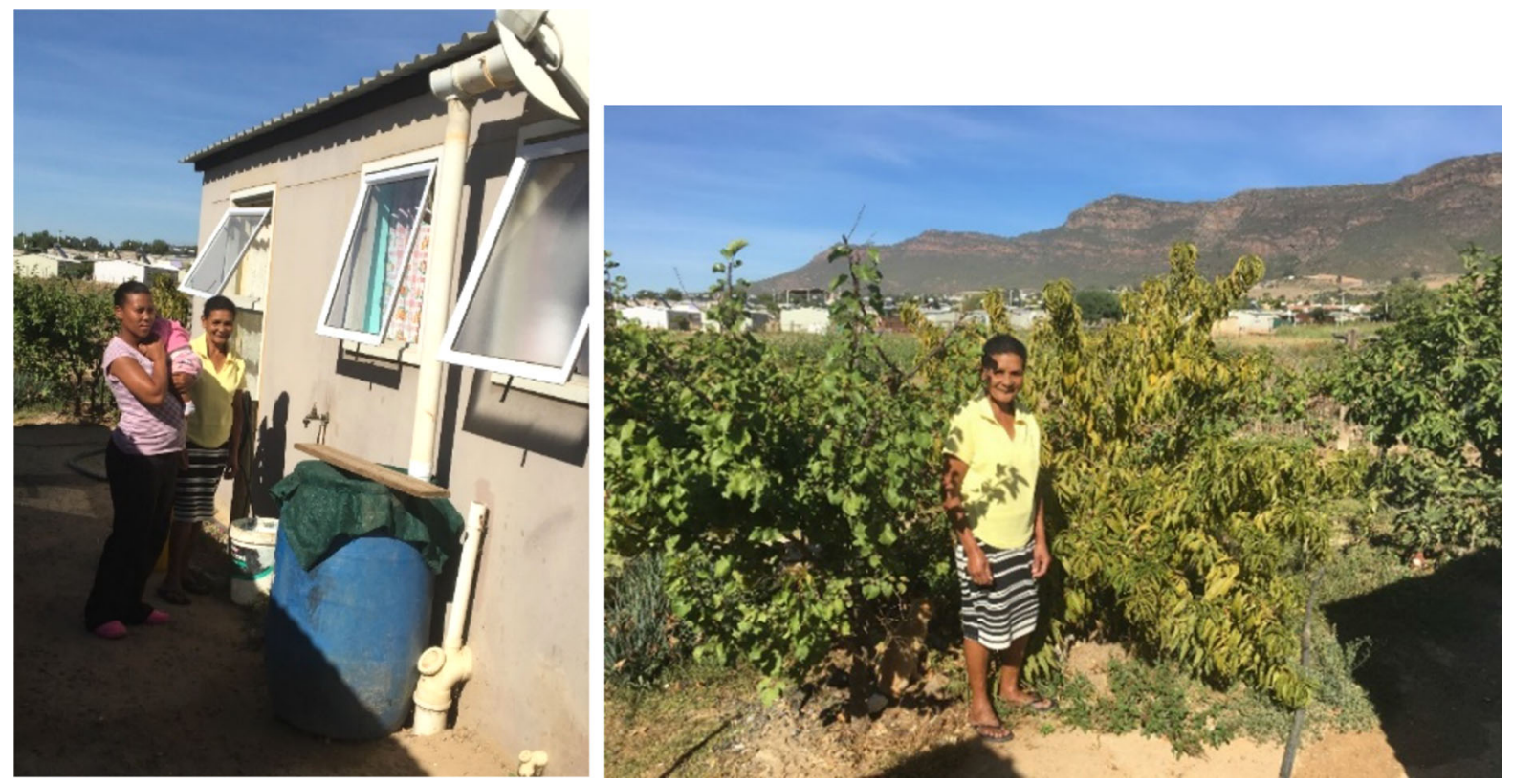

Fig. 3 Household water harvesting and use in Piketberg

Table 5 The authorities dealt very effectively with the drought disaster situation

\begin{tabular}{lccccccc}
\hline & $\begin{array}{l}\text { Clanwilliam } \\
(\%)\end{array}$ & $\begin{array}{l}\text { Piketberg } \\
(\%)\end{array}$ & $\begin{array}{l}\text { CoCT- } \\
\text { SOUTH- } \\
\text { EAST }(\%)\end{array}$ & $\begin{array}{l}\text { CoCT-CENTRAL } \\
\text { MIDDLE-INCOME } \\
(\%)\end{array}$ & $\begin{array}{l}\text { CoCT- } \\
\text { NORTH } \\
(\%)\end{array}$ & $\begin{array}{l}\text { CoCT- } \\
\text { SOUTH } \\
(\%)\end{array}$ & $\begin{array}{l}\text { CoCT-CENTRAL } \\
\text { LOW-INCOME (\%) }\end{array}$ \\
\hline $\begin{array}{c}\text { Strongly } \\
\text { disagree }\end{array}$ & 10.7 & 12.9 & 12.8 & 10.7 & 9.6 & 13.0 & 11.4 \\
Disagree & 23.2 & 14.5 & 15.4 & 50.0 & 25.8 & 30.4 & 22.8 \\
Neutral & 19.6 & 4.8 & 35.9 & 10.7 & 25.8 & 34.8 & 22.8 \\
Agree & 39.4 & 53.3 & 28.2 & 14.3 & 32.3 & 13.0 & 32.9 \\
$\begin{array}{c}\text { Strongly } \\
\text { agree }\end{array}$ & 7.1 & 14.5 & 7.7 & 14.3 & 6.5 & 8.8 & 10.1 \\
Total & 100.0 & 100.0 & 100.0 & 100.0 & 100.0 & 100.0 & 100.0 \\
\hline
\end{tabular}

Significance: $\mathrm{X}^{2}=50.539 ; \mathrm{df}=24 ;$ sig. $=0.001$

\section{Behaviour change and awareness of the need to use less water}

Residents of the Western Cape were exposed to numerous press, social and national government messages on all media platforms about the urgency of the drought situation and the critical need to save water. These messages were sometimes emotive in order to illicit behaviour change. More than half (58\%) agreed or strongly agreed that the public cooperated well with the water restrictions that were imposed.
Only $24 \%$ of respondents disagreed (or strongly disagreed) and $16 \%$ were neutral. Older respondents $(70+$ years $)$ were more likely than their younger counterparts, and males more likely (66\%) than females (55\%) (Fig. 4) to say the public cooperated. Agreement or strong agreement was much higher in CoCT-CMI (93\%), CoCT-S (78\%), and Piketberg $(68 \%)$ than in CoCT-CLI $(53 \%)$, CoCT-N (52\%), CoCT-SSE (49\%) and Clanwilliam (44\%) (Table 6).

Respondents were asked an open question about how they had saved water. Thematic coding yielded 


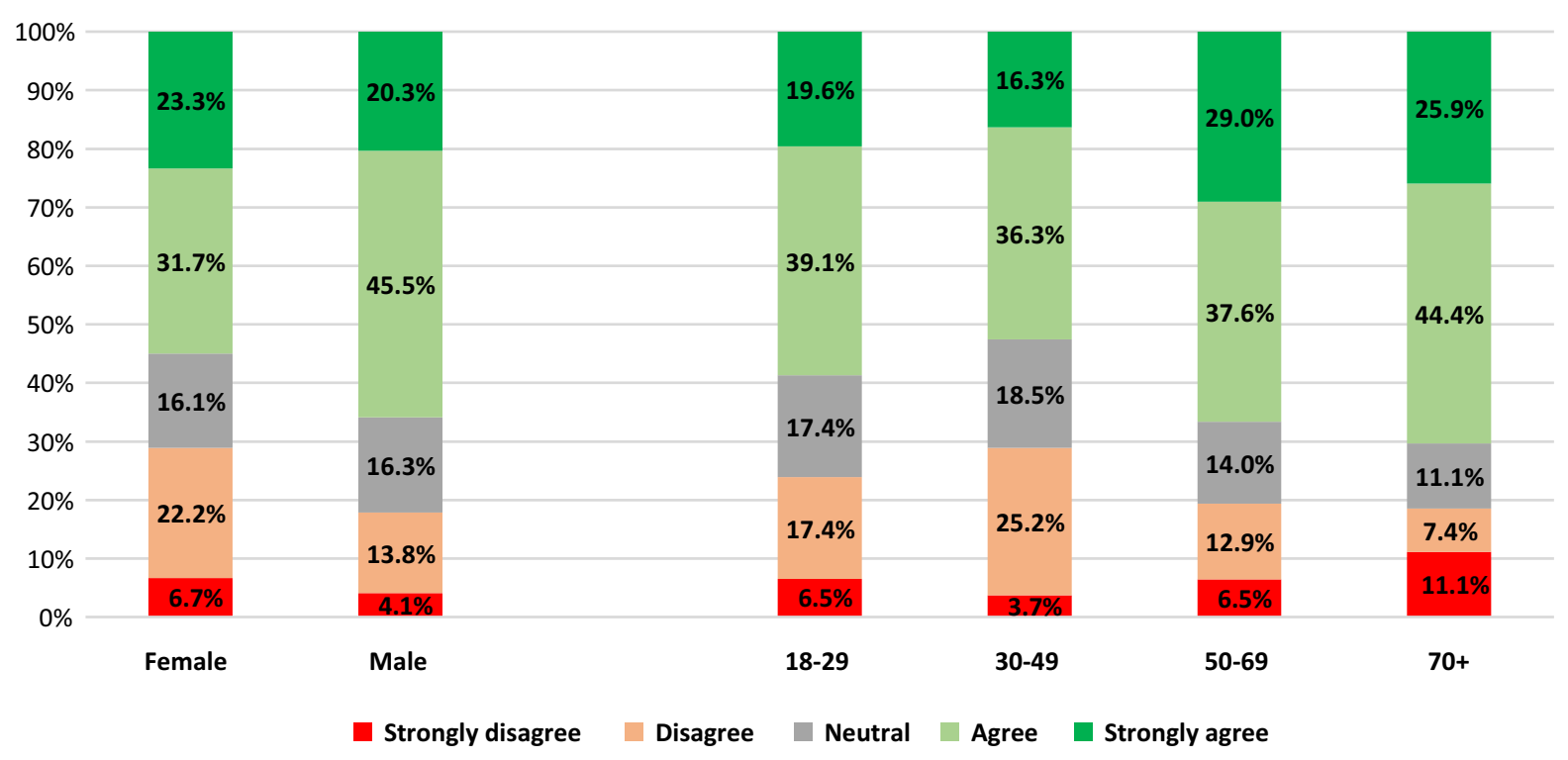

Fig. 4 The public cooperated well with the water restrictions, by gender and age group

Table 6 The public cooperated well with the water restrictions that were imposed

\begin{tabular}{lcclcccc}
\hline & $\begin{array}{l}\text { Clanwilliam } \\
(\%)\end{array}$ & $\begin{array}{l}\text { Piketberg } \\
(\%)\end{array}$ & $\begin{array}{l}\text { CoCT- } \\
\text { SOUTH- } \\
\text { EAST }(\%)\end{array}$ & $\begin{array}{l}\text { CoCT-CENTRAL } \\
\text { MIDDLE-INCOME } \\
(\%)\end{array}$ & $\begin{array}{l}\text { CoCT- } \\
\text { NORTH } \\
(\%)\end{array}$ & $\begin{array}{l}\text { CoCT- } \\
\text { SOUTH } \\
(\%)\end{array}$ & $\begin{array}{l}\text { CoCT-CENTRAL } \\
\text { LOW-INCOME (\%) }\end{array}$ \\
\hline $\begin{array}{c}\text { Strongly } \\
\text { disagree }\end{array}$ & 7.3 & 4.8 & 5.1 & 0.0 & 6.5 & 0.0 & 9.1 \\
$\begin{array}{l}\text { Disagree } \\
\text { Neutral }\end{array}$ & 30.8 & 14.3 & 20.5 & 3.6 & 25.8 & 4.3 & 19.7 \\
Agree & 18.2 & 12.7 & 25.7 & 3.6 & 16.1 & 17.4 & 18.2 \\
$\begin{array}{l}\text { Strongly } \\
\text { agree }\end{array}$ & 5.5 & 28.6 & 33.3 & 50.0 & 38.7 & 56.5 & 34.8 \\
Total & 100.0 & 100.0 & 100.0 & 100.0 & 12.9 & 21.8 & 18.2 \\
\hline
\end{tabular}

Significance: $\mathrm{X}^{2}=51.104 ; \mathrm{df}=24$; sig. $=0.001$

three major categories: recycling (34\%), use of less water $(34 \%)$ and storage of water $(18 \%)$, with smaller proportions indicating other methods (Table 7). The use of less water was the major strategy implemented by respondents in CoCT-CMI (46\%), Clanwilliam (42\%) and CoCT-CLI (35\%). Recycling of water was the method most adopted in CoCT-S (46\%), Piketberg (38\%) CoCT-SE (36\%) and CoCT-N (31\%).

Media and awareness campaigns by NGOs and community-based organisations supplemented the messages emerging from government. An unintended consequence was reduced municipal revenue as a result of reduced water consumption. ${ }^{3}$

\footnotetext{
${ }^{3}$ Groundup (Jones 2018) reported "The tariff for water usage between zero and 6000 litres would increase from R26.25 per 1000 litres to R40.73. And the tariff for usage between 6000 and 10,500 litres would increase from R46.00 per 1000 litres to R48.88.... But monthly water usage between 10,500 and 35,000 litres would still carry a much higher tariff: R127.13 per 1000 litres. Using more than 35,000 litres of water will cost R768.64 per 1000 litres, which the City describes as punitive. (10,500 litres per month is exactly equivalent to a family of seven using 50 litres per day each in a 30-day month". https:// www.groundup.org.za/article/city-explains-new-water-tariffs/.
} 
Table 7 What were the main ways your household or business saved water?

\begin{tabular}{llllllll}
\hline & $\begin{array}{l}\text { Clanwilliam } \\
(\%)\end{array}$ & $\begin{array}{l}\text { Piketberg } \\
(\%)\end{array}$ & $\begin{array}{l}\text { CoCT- } \\
\text { SOUTH- } \\
\text { EAST }(\%)\end{array}$ & $\begin{array}{l}\text { CoCT-CENTRAL } \\
\text { MIDDLE-INCOME } \\
(\%)\end{array}$ & $\begin{array}{l}\text { CoCT- } \\
\text { NORTH } \\
(\%)\end{array}$ & $\begin{array}{l}\text { CoCT- } \\
\text { SOUTH } \\
(\%)\end{array}$ & $\begin{array}{l}\text { CoCT-CENTRAL } \\
\text { LOW-INCOME }(\%)\end{array}$ \\
\hline $\begin{array}{c}\text { Used less } \\
\text { water }\end{array}$ & 42.0 & 26.7 & 33.3 & 46.4 & 23.1 & 22.7 & 34.8 \\
$\begin{array}{c}\text { Recycled } \\
\text { water }\end{array}$ & 36.0 & 38.3 & 36.4 & 25.0 & 30.8 & 45.5 & 20.3 \\
$\begin{array}{c}\text { Stored } \\
\text { water }\end{array}$ & 18.0 & 20.0 & 12.1 & 25.0 & 15.4 & 4.5 & 23.2 \\
$\begin{array}{c}\text { Fixed } \\
\text { leakages }\end{array}$ & 0.0 & 1.7 & 0.0 & 3.6 & 3.8 & 0.0 & 4.3 \\
$\begin{array}{c}\text { Other } \\
\text { methods }\end{array}$ & 2.0 & 0.0 & 18.2 & 0.0 & 26.9 & 27.3 & 11.6 \\
$\begin{array}{c}\text { Did not } \\
\text { save } \\
\text { water }\end{array}$ & 2.0 & 13.3 & 0.0 & 0.0 & 0.0 & 0.0 & 5.8 \\
\begin{tabular}{c} 
Total \\
\hline
\end{tabular} & 100.0 & 100.0 & 100.0 & 100.0 & & 100.0 & 100.0 \\
\hline
\end{tabular}

Significance: $X^{2}=65.580 ; \mathrm{df}=30 ;$ sig. $=0.000$

Few residents of the Western Cape were unaware of the drought and the need to save water, as confirmed by the $80 \%$ who agreed or strongly agreed that 'Most people in the Western Cape are now very aware of the need to save water'. Although variations between areas were not statistically significant, older respondents $(70+)$ were more likely to recognise general public awareness of the need to save water (89\%) than were those aged $18-29$ years $(77 \%)$. A higher proportion of males $(86 \%)$ than females $(78 \%)$ agreed.

\section{Conclusions}

This paper sets out to assess the extent of intra- and inter-urban differences in response to the severe Western Cape drought of 2016-2018. A survey of 240 households and 71 businesses or organisations collected data on attitudes about government management of the situation; mitigation measures implemented; and suggestions for improved handling of any future drought disasters.

Almost all respondents indicated their awareness, or at least partial awareness of the drought and the water restrictions that were imposed. Significantly, almost $20 \%$ of respondents from the surveyed lowincome township (Langa) said that they were not aware of the water restrictions, reflective of their normal lower usage patterns. Awareness of water restrictions increased with age, those aged 50 to $70+$ years more likely to have been aware than their younger counterparts. About half of the respondents had been satisfied with the municipal management approach and communication methods. Dissatisfaction was most prevalent amongst those living in poorer neighbourhoods, those aged 30 years or more, as well as residents of a middle-income neighbourhood with some other specific political grievances about the metropolitan government. The most serious effects of the drought were reported as being on hygiene and household duties, significantly more so in Cape Town's middle-income suburbs and Piketberg, and amongst the oldest and youngest respondents. The maintenance of gardens was mentioned more in Clanwilliam than elsewhere, household budgets (with water being more expensive) appeared to be affected most in Cape Town's east-middle-income area and amongst respondents aged over 50. The running of businesses was affected, especially in northern Cape Town. Residents in the south were more likely than those living elsewhere, to think that the public cooperated well with the water restrictions. Common household drought mitigation strategies were to use less water; to flush toilets and to water gardens with 
recycled water (especially in the south, east and small towns); to acquire storage facilities (central middleincome and low-income areas); and to access water from non-municipal sources such as wells and springs. Middle-income households and water-intensive businesses incurred greater impact on activities such as maintaining gardens and topping up swimming pools. Conversely, the impact was much less for low-income households and small non-water intensive businesses. Suggestions for the management of future droughts were for increased water saving (22\%), enhanced communication and awareness (19\%) including greater use of social media, improved infrastructure and resources $(18 \%)$, continuation of water restrictions $(9 \%)$ (this view was strongest amongst the under$30 \mathrm{~s}$ ), and public provision of water tanks (7\%) (notably in the small towns) and boreholes (6\%).

Acknowledgements This research was made possible by a generous grant from the CEO of the Human Sciences Research Council, South Africa. The time given by the survey respondents and the city official for the sharing of experiences was highly appreciated.

\section{References}

Baumwoll, J. (2008). The value of indigenous knowledge for disaster risk reduction: A unique assessment tool for reducing community vulnerability to natural disasters. Webster University, ProQuest Dissertations Publishing. 1452475.

Berkes, F. (2008). Community conserved areas: Policy issues in historic and contemporary context. Conservation Letters, 2(1), 20-25.

Birkmann, J., Garschagen, M., Kraas, F., \& Quang, N. (2010). Adaptive urban governance: New challenges for the second generation of urban adaptation strategies to climate change. Sustainability Science, 5(2), 185-206. https://doi. org/10.1007/s11625-010-0111-3.

Botha, D., \& Van Niekerk, D. (2013). Views from the frontline: A critical assessment of local risk governance in South Africa. Jàmbá: Journal of Disaster Risk Studies, 5(2), Art. \#82. https://doi.org/10.4102/jamba.v5i2.82.

Brooks, R. H. (1982). The adversity of Brazilian drought. GeoJournal, 6(2), 121-128. https://doi.org/10.1007/ BF00185534.

Bruvold, W. H. (1979). Residential response to urban drought in central California. Water Resources Research, 15(6), 1297-1304. https://doi.org/10.1029/WR015i006p01297.

Buurman, J., Mens, M. J. P., \& Dahm, R. J. (2017). Strategies for urban drought risk management: A comparison of 10 large cities. International Journal of Water Resources Development, 33(1), 31-50. https://doi.org/10.1080/07900627. 2016.1138398 .
Campisano, A., \& Modica, C. (2010). Experimental investigation on water saving by the reuse of washbasin grey water for toilet flushing. Urban Water Journal, 7(1), 17-24. https://doi.org/10.1080/15730621003596739.

City of Cape Town. (2019a). Water Dashboard. http://coct.co/ water-dashboard/.

City of Cape Town. (2019b). http://www.capetown.gov.za.

Daskon, C., \& Binns, T. (2010). Culture, tradition and sustainable rural livelihoods: Exploring the culture-development interface in Kandy, Sri Lanka. Community Development Journal, 45(4), 494-517.

de Matos Carlos, S., da Cunha, D. A., Pires, M. V., \& Rito do Couto-Santos, F. (2019). Understanding farmers' perceptions and adaptation to climate change: The case of Rio das Contas basin, Brazil. GeoJournal. https://doi.org/10.1007/ s10708-019-09993-1.

Hewitt, K. (2007). Preventable disasters: Addressing social vulnerability, institutional risk, and civil ethics. Geographische Rundschau, International Edition, 3(1), 43-52.

Huntington, H. P., Gearheard, S., Mahoney, A. R., \& Salomon, A. K. (2011). Integrating traditional and scientific knowledge through collaborative natural science field research: Identifying elements for success. Arctic, 64(4), 437-445.

Independent Electoral Commission (IEC) of the Republic of South Africa. 2019. http://www.elections.org.za/content/ Elections/Municipal-elections-results/.

Jones, A. (2018). How Cape Town more than halved it's water usage. GroundUp article. Daily Maverick. https://www. dailymaverick.co.za/article/2018-03-13-groundup-howcape-town-more-than-halved-its-water-usage/.

Kaiser, G., \& Macleod, N. (2018). Cape Town-Where we've been and where we want to go. Civil Engineering, 26(9), $8-12$.

Kamara, J. (2005). Indigenous knowledge in natural disaster reduction in Africa.http://www.grida.no/_res/site/File/ publications/environmenttimes/kobetimes_01.pdf.

Lindner, E. G. (2008). Disasters as a chance to implement novel solutions that highlight attention to human dignity disasters and innovative solutions. In A. Awotona (Ed.), A sociological perspective on disasters. Proceedings: An international conference on rebuilding sustainable communities for children and their families after disasters. Boston: University of Massachusetts.

Lunga, W., \& Musarurwa, C. (2016). Exploiting indigenous knowledge commonwealth to mitigate disasters: From the archives of vulnerable communities in Zimbabwe. Indian Journal of Traditional Knowledge, 15(1), 22-29.

Magnan, A. K., Schipper, E. L. F., Burkett, M., Bharwani, S., Burton, I., Eriksen, S., et al. (2016). Addressing the risk of maladaptation to climate change. WIREs Climate Change, 7(5), 646-665. https://doi.org/10.1002/wcc.409.

Marango, T., Francis, J., \& Mathaulula, M. A. (2016). Insights into the potential of indigenous rain making practices in combating the negative effects of climate change in Chimanimani District of Zimbabwe. INDILINGA, 15(2), 192-208.

Mathivha, F. I., Tshipala, N. N., \& Nkuna, Z. (2017). The relationship between drought and tourist arrivals: A case study of Kruger National Park, South Africa. Jàmbá: 
Journal of Disaster Risk Studies, 9(1), a471. https://doi. org/10.4102/jamba.v9i1.471.

Miller, E., \& Buys, L. (2008). The Impact of Social capital on residential water-affecting behaviours in a drought-prone Australian community. Society and Natural Resources, 21(3), 244-257. Copyright 2008 Taylor \& Francis. Accessed from http://eprints.qut.edu.au.

Mortazavi, M., Kuczera, G., Kiem, A. S., Henley, B., Berghout, B., \& Turner, E. (2013). Robust optimisation of urban drought security for an uncertain climate (p. 74). Gold Coast: National Climate Change Adaptation Research Facility.

Mudombi, S., Fabricius, C., Van Zyl-Bulitta, V., \& Patt, A. (2017). The use of and obstacles to social learning in climate change adaptation initiatives in South Africa. Jàmbá: Journal of Disaster Risk Studies, 9(1), a292. https://doi. org/10.4102/jamba.v9i1.292.

Musarandega, H., Chingombe, W., \& Pillay, R. (2018). Harnessing local traditional authorities as a potential strategy to combat the vagaries of climate change in Zimbabwe. Jàmbá: Journal of Disaster Risk Studies, 10(1), a651. https://doi.org/10.4102/jamba.v10i1.651.

Muyambo, F., Jordaan, A. J., \& Bahta, Y. T. (2017). Assessing social vulnerability to drought in South Africa: Policy implication for drought risk reduction. Jàmbá: Journal of Disaster Risk Studies, 9(1), a326. https://doi.org/10.4102/ jamba.v9i1.326onx.

Mwaura, P. (2008). Indigenous knowledge in disaster management in Africa (p. 117). Nairobi: UNEP.

News24. (2019). https://m.news24.com/SouthAfrica/News/ severe-water-shortages-a-norm-in-some-towns-20190328.

Nunes, A. R. (2016). Assets for health: Linking vulnerability, resilience and adaptation to climate change. University of Warwick (Tyndall Centre for Climate Change Research Working Paper 163).

Nunn, P. D., Hunter-Anderson, R., Carson, M. T., Thomas, F., Ulm, S., \& Rowland, M. J. (2007). Times of plenty, times of less: Last-millennium societal disruption in the Pacific basin. Human Ecology, 35(4), 385-401.

Odendaal, N. (2019). https://www.engineeringnews.co.za/ article/western-cape-dams-reach-highest-levels-in-fouryears-2019-08-05.

Okaka, F. O., \& Odhiambo, B. D. O. (2018). Urban residents' awareness of climate change and their autonomous adaptive behavior and mitigation measures in the coastal city of Mombasa, Kenya. South African Geographical Journal, 100(3), 378-393.

Onyx, J., \& Bullen, P. (2000). Measuring social capital in five communities. Journal of Applied Behavioural Science, 36(1), 23-42.
Otto, I. M., Reckien, D., Reyer, C. P. O., Marcus, R., Le Masson, V., Jones, L., et al. (2017). Social vulnerability to climate change: A review of concepts and evidence. Regional Environmental Change, 17(6), 1651-1662.

Putnam, R. D. (2000). Bowling alone: The collapse and revival of American Community. New York: Simon \& Schuster.

Reibel, M., Glickfield, M., \& Roquemore, P. (2020). Disadvantaged communities and drinking water: A case study of Los Angeles County. GeoJournal. https://doi.org/10.1007/ s10708-019-10121-2.

Republic of South Africa. (2015). Government Gazette, 2015, Act No.16 of 2015: Disaster Management Amendment Act, 2015. Cape Town: Government Gazette of Republic of South Africa.

SA History. (2019). https://www.sahistory.org.za/place/langatownship.

Schuman, S., Dokken, J., van Niekerk, D., \& Loubser, R. A. (2018). Religious beliefs and climate change adaptation: A study of three rural South African communities. JambaJournal of Disaster Risk Studies, 10(1), 1-12.

Selman, P. (2001). Social capital, sustainability and environmental planning. Planning Theory \& Practice, 2(1), 13-30.

Shaw, D. T., Henderson, R. T., \& Cardona, M. (1992). Urban drought response in Southern California: 1990-91. American Water Works Association, 84(10), 34-41. https://doi. org/10.1002/j.1551-8833.1992.tb05862.x.

Singh, A., \& Singh, R. B. (2006). Community participation in disaster mitigation. Chapter 20 In Singh, R. B. (Ed.) Natural hazards and disaster management (pp. 313-320). Reprinted 2018. New Delhi: Rawat Publications.

Smit, B., \& Wandel, J. (2006). Adaptation, adaptive capacity and vulnerability. Global Environmental Change, 16(3), 282-292. https://doi.org/10.1016/j.gloenvcha.2006.03. 008 .

van Niekerk, D. (2014). A critical analysis of the South African Disaster Management Act and policy framework. Disasters, 38(4), 858-877.

Ziervogel, G. (2019). Unpacking the Cape Town Drought: Lessons learned. Report for cities support programme. Undertaken by African Centre for Cities.

Publisher's Note Springer Nature remains neutral with regard to jurisdictional claims in published maps and institutional affiliations. 


\section{Terms and Conditions}

Springer Nature journal content, brought to you courtesy of Springer Nature Customer Service Center GmbH ("Springer Nature"). Springer Nature supports a reasonable amount of sharing of research papers by authors, subscribers and authorised users ("Users"), for small-scale personal, non-commercial use provided that all copyright, trade and service marks and other proprietary notices are maintained. By accessing, sharing, receiving or otherwise using the Springer Nature journal content you agree to these terms of use ("Terms"). For these purposes, Springer Nature considers academic use (by researchers and students) to be non-commercial.

These Terms are supplementary and will apply in addition to any applicable website terms and conditions, a relevant site licence or a personal subscription. These Terms will prevail over any conflict or ambiguity with regards to the relevant terms, a site licence or a personal subscription (to the extent of the conflict or ambiguity only). For Creative Commons-licensed articles, the terms of the Creative Commons license used will apply.

We collect and use personal data to provide access to the Springer Nature journal content. We may also use these personal data internally within ResearchGate and Springer Nature and as agreed share it, in an anonymised way, for purposes of tracking, analysis and reporting. We will not otherwise disclose your personal data outside the ResearchGate or the Springer Nature group of companies unless we have your permission as detailed in the Privacy Policy.

While Users may use the Springer Nature journal content for small scale, personal non-commercial use, it is important to note that Users may not:

1. use such content for the purpose of providing other users with access on a regular or large scale basis or as a means to circumvent access control;

2. use such content where to do so would be considered a criminal or statutory offence in any jurisdiction, or gives rise to civil liability, or is otherwise unlawful;

3. falsely or misleadingly imply or suggest endorsement, approval, sponsorship, or association unless explicitly agreed to by Springer Nature in writing;

4. use bots or other automated methods to access the content or redirect messages

5. override any security feature or exclusionary protocol; or

6. share the content in order to create substitute for Springer Nature products or services or a systematic database of Springer

Nature journal content.

In line with the restriction against commercial use, Springer Nature does not permit the creation of a product or service that creates revenue, royalties, rent or income from our content or its inclusion as part of a paid for service or for other commercial gain. Springer Nature journal content cannot be used for inter-library loans and librarians may not upload Springer Nature journal content on a large scale into their, or any other, institutional repository.

These terms of use are reviewed regularly and may be amended at any time. Springer Nature is not obligated to publish any information or content on this website and may remove it or features or functionality at our sole discretion, at any time with or without notice. Springer Nature may revoke this licence to you at any time and remove access to any copies of the Springer Nature journal content which have been saved.

To the fullest extent permitted by law, Springer Nature makes no warranties, representations or guarantees to Users, either express or implied with respect to the Springer nature journal content and all parties disclaim and waive any implied warranties or warranties imposed by law, including merchantability or fitness for any particular purpose.

Please note that these rights do not automatically extend to content, data or other material published by Springer Nature that may be licensed from third parties.

If you would like to use or distribute our Springer Nature journal content to a wider audience or on a regular basis or in any other manner not expressly permitted by these Terms, please contact Springer Nature at

onlineservice@springernature.com 